\title{
Co-immobilization of P450 BM3 and glucose dehydrogenase on different supports for application as a self-sufficient oxidative biocatalyst
}

\author{
Jordi Solé, ${ }^{\mathrm{a}}$ Gloria Caminal, ${ }^{\mathrm{b}}$ Martin Schürmann, ${ }^{\mathrm{c}}$ Gregorio Álvaro ${ }^{\mathrm{a}}{ }_{\odot}$ \\ and Marina Guillén ${ }^{a^{*} \odot}$
}

\begin{abstract}
BACKGROUND: The oxy-functionalization of non-activated carbon bonds by the bacterial cytochrome P450 BM3 from Bacillus megaterium, presents a promising field in biosynthesis and it has gained much interest in recent decades. Nevertheless, the need for the expensive cofactor NADPH, together with low operational stability of the enzyme have made the implementation of this biocatalyst unfeasible in most cases for industry.

RESULTS: P450 BM3 and glucose dehydrogenase (GDH), as a cofactor regeneration enzyme, were successfully co-immobilized obtaining a bi-functional self-sufficient oxidative biocatalyst. First, a broad screening of 13 different supports was carried out. Five selected agaroses with three different functionalities (epoxy, amine and aldehyde) were studied and their immobilization processes optimized. Finally, P450 BM3 and GDH were co-immobilized on those supports showing the best performance for P450 BM3 immobilization: epoxy-agarose (epoxy-agarose-UAB) presenting $83 \%$ and $20 \%$ retained activities respectively; AMINO-agarose presenting $28 \%$ and $25 \%$, and Lentikats ${ }^{\circledR}$ with which both enzymes retained $100 \%$ of the initial activity. Furthermore, the re-utilization of the self-sufficient immobilized derivatives was tested in five repeated cycles.
\end{abstract}

CONCLUSIONS: P450 BM3 and GDH have been successfully immobilized on three supports and their re-usability has been tested in a model reaction. It represents a step forward for future P450 BM3 industrial implementations.

(c) 2018 Society of Chemical Industry

Keywords: immobilization; biocatalysis; enzymes; oxidation

\section{INTRODUCTION}

Cytochromes P450 (CYPs) are versatile monooxygenases able to hydroxylate non-activated carbon bonds with the only requirement being molecular oxygen and an electron donor. CYPs are found as: (i) double domain proteins, presenting a heme-containing oxidative part and a FAD-/FMN-containing reductase; as (ii) triple domain enzymes with a third Ferredoxin subunit; and (iii) as fusion proteins with just one enzymatic unit. ${ }^{1}$ These enzymes have been the focus of research in recent decades due to interest in their application as catalysts for the efficient production of fine chemicals, polymers, active pharmaceutical ingredients or nutritional supplements. They display a broad substrate range as well as the capability to catalyse a variety of oxidations including epoxidations, hydroxylation of aromatics, $\mathrm{N}$-oxidation, deamination, dehalogenation and others. ${ }^{2}$

P450 BM3 (EC 1.14.14.1) from Bacillus megaterium was discovered in 1986 and excels among CYPs because it presents the highest turnover numbers (17000 $\mathrm{min}^{-1}$ for arachidonic acid) $)^{3,4}$ In contrast with eukaryotic CYPs, P450 BM3 is a self-sufficient soluble protein that contains both oxidative and reductase domains in the same polypeptide chain. Its natural substrates are medium to long chain fatty acids, however, as with other CYPs, P450 BM3 is a promiscuous enzyme. It accepts fatty amides and alcohols, hydroxylated fatty acids and $\omega$-oxo fatty acids. It also displays, not only hydroxylating activity, but olefin epoxidation, ring expansion, heteroatom oxidation and dealkylation, and dehydrogenation across $\mathrm{C}-\mathrm{O}, \mathrm{C}-\mathrm{N}$ and $\mathrm{C}-\mathrm{C}$ bonds, as well as carbon-carbon bond formation and cleavage. ${ }^{5}$

There are some limitations to the large-scale application of P450 BM3, such as low operational stability, a dependence on the expensive NADPH electron donor and low retained activity in organic media. ${ }^{6}$ Thus, there have been few cases where it has been attempted to use it industrially. ${ }^{7,8}$ In order to tackle these

\footnotetext{
* Correspondence to: M Guillén, Department of Chemical, Biological and Environmental Engineering, Universitat Autònoma de Barcelona (UAB), $08193 \mathrm{Bel}$ laterra, Catalonia, Spain. E-mail: marina.guillen@uab.cat

a Bioprocess Engineering and Applied Biocatalysis Group, Department of Chemical Biological and Environmental Engineering, Universitat Autònoma de Barcelona, Bellaterra, Spain

b Institut de Química Avançada de Catalunya (IQAC) CSIC, Barcelona, Spain

c InnoSyn B.V., Urmonderbaan 22, Geleen, The Netherlands
} 
bottlenecks, protein engineering, cofactor recycling systems, surface modifications, reaction media engineering or immobilization are the main strategies usually followed in biocatalytic processes.

Regarding the low operational stability, immobilization has proven to be an efficient methodology for a broad type of oxidoreductases, not only for improving their stability but also for enhancing process metrics by biocatalyst recycling. ${ }^{9,10}$ In addition, immobilization can confer operational advantages such as the possibility to operate in continuous mode, reduction of foam formation, increased stability in organic solvents or simplified product purification. ${ }^{11,12}$ Immobilization of P450 BM3 has been pursued by other authors. For example, Maurer et al. tried to immobilize it on a variety of commercially available supports. ${ }^{13}$ They succeeded using the positively charged resins DEAE and SuperQ; and a Sol-Gel, but only the last one was found suitable for bioconversions. Axarli et al. immobilized a triple mutant onto epoxy-sepharose, achieving retained activities of $81 \%$ and improved stabilities at $37^{\circ} \mathrm{C}^{14}$ Weber et al. entrapped the heme-domain of the P450 BM3 into mesoporous molecular sieves (MCM-41 and SBA-15) and found a correlation between the activity observed from the derivative and pore diameter. ${ }^{15}$ Furthermore, Zhao et al. immobilized a mutant on DEAE-650S, further entrapped into k-carrageenan together with catalase and zinc dust (Zn/Co(III)sep) which served as electron source. They could operate the reactor over 10 batch cycles with continued conversions above $80 \% .{ }^{16}$ Other successful and more recent examples involved the fusion of the enzyme to linkers that enabled immobilization on solid surfaces. ${ }^{17-19}$ From all the work present in the literature, there are few cases where P450 BM3 has been successfully immobilized covalently for bioconversion purposes. Many of the above works focused on bio-sensing, in which low amounts of enzyme are required, or on the electrochemical study of the enzyme. ${ }^{20}$ For large-scale applications, the attachment of large quantities of the enzyme to solid matrices by covalent bonds is a robust method that often confers novel properties to the enzyme and it does not present leaching.

With regard to electron donors, there have been attempts to substitute the expensive NADPH co-substrate for less costly products, e.g. $\mathrm{NADH}$ or $\mathrm{H}_{2} \mathrm{O}_{2}$ by protein engineering. ${ }^{21-23}$ In a different way, electrochemical-driven catalysis has also proved a successful method to bypass the use of NADPH. In various works, the immobilization of P450s on electrode surfaces that served as electron sources led to enzymatically catalysed product formation..$^{24-27}$ Strategies for regenerating the expensive NADPH have also been studied both in enzymatic and non-enzymatic manners. ${ }^{28-30}$ The use of whole cell biocatalyst expressing P450 has been considered as a suitable and much cheaper strategy by taking advantage of the cellular metabolism for NADPH regeneration. ${ }^{31,32}$ However, the use of whole cells entails several drawbacks such as secondary undesired reactions or low reaction rates due to substrate or product mass transfer limitation. Among the different strategies for cofactor regeneration, the utilization of secondary enzymes that make use of sacrificial substrates is one of the most attractive systems. The use of enzymatic NADPH regeneration systems in P450-catalysed reactions has been reported by other authors. Different enzymes such as glucose dehydrogenase, formate dehydrogenase or phosphite dehydrogenase proved to be efficient and suitable biocatalysts for this purpose. ${ }^{13,33-35}$

In this work, a bi-functional self-sufficient oxidative biocatalyst is obtained by the successful co-immobilization of P450 BM3 and a GDH from Thermoplasma acidophilum as cofactor-regenerating enzyme (Fig. 1). First, P450 immobilization was analysed prior to

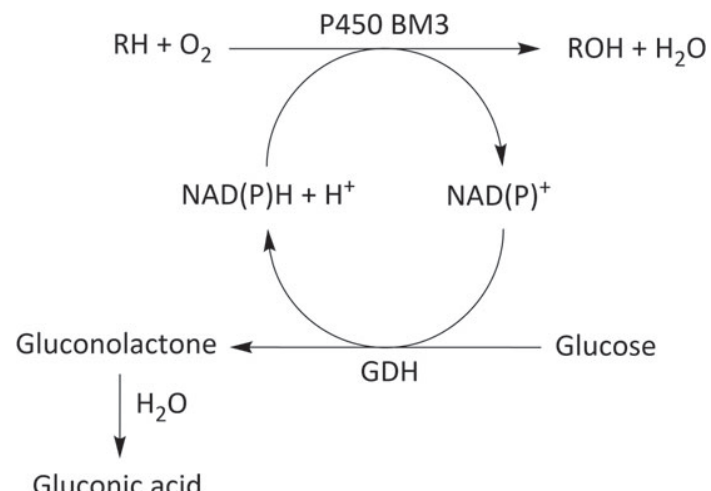

Gluconic acid

Figure 1. Scheme of the bi-functional self-sufficient oxidative biocatalyst obtained by the co-immobilization of P450 BM3 from Bacillus megaterium and a GDH from Thermoplasma acidophilum as cofactor-regenerating enzyme.

selection of the best co-immobilization strategy since P450 is a less robust enzyme compared with GDH. Thus, deeper understanding of P450 BM3 immobilization by two different enzyme-support interactions (adsorption or covalent attachment) is presented. In this sense, different supports presenting a broad range of features were tested to gain insight to the optimal immobilization procedure that should be followed. Finally, co-immobilization of P450 BM3 and GDH was performed by applying the best methodologies resulting for the $\mathrm{P} 450 \mathrm{BM} 3$. The encapsulation in polyvinyl alcohol particles (Lentikats ${ }^{\circledR}$ ) was also studied for the confinement of both P450 BM3 and GDH as an alternative to adsorption and covalent attachment strategies.

The resulting self-sufficient biocatalysts were tested in terms of operational stability in the hydroxylation of sodium laureate as a model reaction for proof-of-concept.

\section{EXPERIMENTAL}

\section{Materials and supports}

Nicotinamide adenine dinucleotide phosphate sodium salts in its oxidized and reduced form (NADP ${ }^{+}$disodium salt and NADPH tetrasodium salt) was purchased from BONTAC Bioengineering (Shenzhen, Guandong, China). All the other reagents were purchased from Sigma Aldrich ${ }^{\circledR}$ (St. Louis, MO, USA) and were of analytical grade if not stated otherwise.

The supports used in the screening section were donated by Purolite ${ }^{\circledR}$ Life Sciences (Bala Cynwyd, PA, USA) and their features are summarized in Table 2.

The epoxy-agarose-SIGMA was purchased from Sigma-Aldrich ${ }^{\circledR}$. According to the supplier's specifications it presented spherical shape, it had an activation degree of $\geq 20 \mu \mathrm{mol} \mathrm{mL}-1$ and 12 atoms spacer.

Non-functionalized agarose (spherical beads $\varnothing 50-150 \mu \mathrm{m}$ ) purchased from Agarose Bead Technologies ${ }^{\circledR}\left(A B T^{\circledR}\right.$, Madrid, Spain) was used to obtain epoxy-agarose-UAB by support functionalization carried out as described by Axarli et al. ${ }^{14}$ The quantification of the epoxy groups present on the supports was done following the method described by Gupta. ${ }^{36}$

Amino functionalized agarose (AMINO-agarose) presenting amino ethyl groups and aldehyde functionalized agarose (GLYOXYL-agarose) with an extent of labelling of $40-60 \mu \mathrm{mol} \mathrm{mL}^{-1}$ both were also purchased from $A B T^{\circledR}$. All this information was always according to the supplier's specifications. 
Lentikats ${ }^{\circledR}$ polymer was purchased from GeniaLab ${ }^{\circledR}$ (Braunschweig, Germany) with composition consisting of a mixture of polyvinyl alcohol (10\%), polyethylene glycol (6\%) and demineralized water (84\%).

\section{Recombinant expression of P450 BM3 and glucose dehydrogenase in E. coli}

P450 BM3 (CYP102A1 from Bacillus megaterium BM3) was recombinantly produced in Escherichia coli in a $20 \mathrm{~L}$ scale batch fermentation employing an $E$. coli $\mathrm{K} 12$ derivative and a pBAD/myc-HisC based expression vector. Glucose dehydrogenase (GDH) from Thermoplasma acidophilum (GDH-Tac) was co-expressed from the same vector in a poly-cistronic arrangement of the GDH gene downstream of the P450 BM3 gene. A $500 \mathrm{~mL}$ pre-culture were used to inoculate $20 \mathrm{~kg}$ main culture medium with $100 \mu \mathrm{g} \mathrm{mL}^{-1}$ neomycin. The pre-culture was prepared in standard Luria-Bertani (LB) medium supplemented with $100 \mu \mathrm{g} \mathrm{mL}^{-1}$ neomycin. The fermentation was performed using terrific broth (TB) medium with glycerol. $2.5 \mathrm{~h}$ after inoculation of the fermenter as inducer, pre-sterilized L-arabinose was added to the fermenter to final concentration $0.02 \%(\mathrm{w} / \mathrm{v})$. Twenty-four hours after inoculation of the fermenter, the cell material was harvested by centrifugation. Cell-free extract was prepared by adding 2 weight equivalents of $100 \mathrm{mmol} \mathrm{L}^{-1}$ potassium phosphate $\left(\mathrm{KP}_{\mathrm{i}}\right)$ buffer $(\mathrm{pH} 7.0)$ to 1 weight equivalent of $E$. coli wet cells and sonication of this cell suspension with an ultrasound probe for $\mathbf{2 0}$ min with cooling on ice and centrifugation to remove the cell-debris.

\section{Total protein and enzyme content}

The cell lysate was pre-clarified by centrifugation (3220 g for $15 \mathrm{~min}$.) and analysed accounting for total protein content by means of Bradford Protein Assay Kit (Thermo Fisher Scientific, Waltham, USA) using bovine serum albumin as standard. ${ }^{37}$

Enzyme content was assessed using sodium dodecyl sulphate polyacrylamide gel electrophoresis (SDS-PAGE) (NuPage 12\%, Invitrogen, USA) run in a Mini-PROTEAN II apparatus (BioRad, USA) following the protocol of Laemmli et al. ${ }^{38}$ Low range protein markers were used for molecular weight determination. Gels were stained using Comassie G250 colloidal stain solution [34\% $(\mathrm{v} / \mathrm{v})$ ethanol, $2 \%(\mathrm{v} / \mathrm{v}) \mathrm{H}_{3} \mathrm{PO}_{4}, 17 \%(\mathrm{w} / \mathrm{v})\left(\mathrm{NH}_{4}\right)_{2} \mathrm{SO}_{4}$ and $0.066 \%$ Comassie G250] and the Image LAB $^{\mathrm{TM}}$ software (BioRad, USA) was used for image processing.

\section{Active P450 BM3 content determination}

P450 BM3 active form concentration was determined using the CO-differential spectra analysis described by Omura and Sato, using $\varepsilon=91 \mathrm{mM}^{-1} \mathrm{~cm}^{-1}$. 39,40

\section{P450 BM3 activity measurement}

The activity of the P450 BM3 was measured spectrophotometrically $(\lambda=340 \mathrm{~nm})$ following the consumption of NADPH

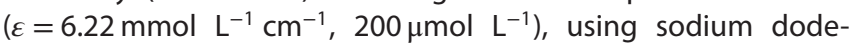
canoate (sodium laurate) as substrate $\left(1.3 \mathrm{mmol} \mathrm{L}^{-1}\right.$ dissolved in sodium phosphate buffer $50 \mathrm{mmol} \mathrm{L}^{-1} \mathrm{pH}=7.5$ ). $25 \mu \mathrm{L}$ of enzyme sample were added to the total volume of the assay $(500 \mu \mathrm{L})$. The basal consumption of NADPH by unspecific enzymes present in the lysate or/and by P450 uncoupling in absence of substrate was determined by this same test but avoiding the addition of the substrate and adding buffer instead. This consumption rate, that represents about $2-3 \%$, is subtracted from the measurement with sodium dodecanoate. One unit of activity $(U)$ is defined as the enzyme required to convert $1 \mu \mathrm{mol}$ of NADPH per minute at those given conditions $\left(30^{\circ} \mathrm{C}\right.$ and $\left.\mathrm{pH}=7.5\right)$. The absorbance was recorded using a spectrophotometer Cary 50 Bio UV-visible (Palo Alto, USA). The equipment allows temperature control and stirring. Plastic micro-cuvettes BRAND ${ }^{\circledR}$ UV (Sigma Aldrich ${ }^{\circledR}$ ) were used for soluble enzyme characterization and $3.5 \mathrm{~mL}$ quartz cuvettes HELLMA ${ }^{\circledR}$ 100-QS (Hellma Analytics, Müllheim, Germany) with magnetic stirring, were used for the immobilized derivatives (suspension). In the first case a total volume of $500 \mu \mathrm{L}$ was reached while in the second it was $2 \mathrm{~mL}$.

\section{Glucose dehydrogenase activity measurement}

GDH activity is measured spectrophotometrically $(\lambda=340 \mathrm{~nm})$ following the formation of NADPH. A specified amount of sample $\left(1 / 20\right.$ of the $\left.V_{T}\right)$ was added to a solution containing D-glucose ( $200 \mathrm{mmol} \mathrm{L}^{-1}$ dissolved in sodium phosphate buffer $100 \mathrm{mmol}$ $\left.\mathrm{L}^{-1} \mathrm{pH}=8\right)$ and $\operatorname{NADP}^{+}\left(400 \mu \mathrm{mol} \mathrm{L} \mathrm{L}^{-1}\right)$. The same procedure explained above was applied for measuring the non-GDH formation of NADPH and the same consideration is taken to obtain the Us. Moreover, it was checked that if NADPH is used instead of $\mathrm{NADP}^{+}$, no consumption of cofactor by $\mathrm{P} 450$ is detected under the test conditions. The absorbance was also recorded using the aforementioned equipment and conditions.

\section{Immobilization metrics}

In every immobilization, a characterization was pursued in order to obtain the retained activity (Eqn (1)) and immobilization yield (Eqn (2)). Supernatant and suspension activities were analysed over time until a steady state was reached and in all cases the activity of a blank (no support) was also monitored to ensure that the enzyme activity was not affected by protocol conditions. A $10 \%$ $\mathrm{w} / \mathrm{v}$ relation between the support and the total volume was always established and small amounts of enzyme were loaded (4-5 U of P450 BM3/g of support and $5-6 \mathrm{U}$ of $\mathrm{GDH} / \mathrm{g}$ of support) so that diffusional limitations were minimized.

$$
\begin{aligned}
& \text { Retained activity }(\%)= \\
& \frac{\text { Suspension activity }\left(\frac{u}{g}\right)-\text { Supernatant activity }\left(\frac{u}{g}\right)}{\text { Initial offered activity }\left(\frac{u}{g}\right)} \times 100
\end{aligned}
$$

Immobilization yield $(\%)=$

$$
\left(1-\frac{\text { Supernatant activity }\left(\frac{u}{g}\right)}{\text { Initial offered activity }\left(\frac{u}{g}\right)}\right) \times 100
$$

For assessment of the loading capacity the supports were saturated with enzyme and the activity was calculated taking into account that diffusional limitations do not allow the actual visualization of the activity in the support (Eqn (3)).

$$
\begin{aligned}
& \text { Loading capacity }\left(\frac{U}{g}\right)=\left(\text { Offered initial activity }\left(\frac{U}{g}\right)\right. \\
& \text {-Supernatant activity } \left.\left(\frac{U}{g}\right)\right) \times \frac{\text { Retained activity }(\%)}{\text { Immobilization yield }(\%)}
\end{aligned}
$$


Moreover, the amount of protein per gram of support was also calculated, analysing the initial protein content and subtracting from it the concentration still remaining in the supernatant at the end of the process. In all cases protein concentration was determined by means of Bradford Protein Assay Kit, as already described.

\section{Immobilization of P450 BM3 onto Purolite ${ }^{\circledR}$ resins}

From Purolite ${ }^{\circledR}$, a set of commercially available resins presenting a variety of matrices, pore sizes, linker lengths, and functional groups (Table 2) were tested for the immobilization of P450 BM3. The conditions in which immobilizations were carried out in each case were those specified by the supplier's protocols. In all cases, the relation of $10 \% \mathrm{w} / \mathrm{v}$ between support and total volume was maintained. The immobilizations were done at $25^{\circ} \mathrm{C}$ and mild agitation. The incubation times ranged from 0.5 to $5 \mathrm{~h}$ depending on the speed at which the enzymes were attached. The epoxy containing methacrylates (ECR8204F, ECR8215F and ECR8285) were used in $50 \mathrm{mmol} \mathrm{L}^{-1}$ sodium phosphate buffer $\mathrm{pH} 8$ containing $0.5 \mathrm{~mol} \mathrm{~L}^{-1} \mathrm{NaCl}$. The amino functionalized resins (ECR8309F, ECR8315F, ECR8409F and ECR8415F) were mixed with the enzyme in $50 \mathrm{mmol} \mathrm{L}^{-1}$ sodium phosphate buffer $\mathrm{pH} 6$. The supports made of a mixture of styrene and methacrylate (ECR1061M and ECR1030M) were utilized in $50 \mathrm{mmol} \mathrm{L}^{-1}$ sodium phosphate buffer $\mathrm{pH}$ 7.5; finally, immobilizations using the epoxy agaroses (Praesto 45,65 and 90 ) were performed in $1 \mathrm{~mol} \mathrm{~L}^{-1}$ potassium phosphate buffer $\mathrm{pH} 8$.

\section{Immobilization of P450 BM3 onto epoxy-agarose-SIGMA and epoxy-agarose-UAB supports}

For the other epoxy-agaroses (epoxy-agarose-SIGMA and epoxy-agarose-UAB), the enzyme was dissolved in $1 \mathrm{~mol} \mathrm{~L}^{-1}$ $(\mathrm{pH} 8)$ potassium phosphate buffer, mixed with the resin $(10 \%$ $\mathrm{w} / \mathrm{v}$ ) and left at $25^{\circ} \mathrm{C}$ with mild agitation. The epoxy-agarose-UAB was incubated for $4 \mathrm{~h}$ and epoxy-agarose-SIGMA was incubated for $0.5 \mathrm{~h}$. At the end of the process, in order to eliminate the unreacted epoxy groups, the samples were incubated with $0.2 \mathrm{M}$ $\beta$-mercaptoethanol for at least $2 \mathrm{~h}$ at $25^{\circ} \mathrm{C}$.

\section{Immobilization of P450 BM3 onto GLYOXYL-agarose support For the immobilization using GLYOXYL-agarose different $\mathrm{pH}$ s were tested (6.5-8.5) using $50 \mathrm{mmol} \mathrm{L}^{-1}$ sodium phosphate buffers. The immobilizations lasted $6 \mathrm{~h}$ and were done at $25^{\circ} \mathrm{C}$ and mild agi- tation. For the reduction of the Schiff base, two different reduc- ing agents were studied: sodium borohydride $\left(1 \mathrm{mg} \mathrm{mL}^{-1}\right)$ added at the end of the immobilization and sodium cyanoborohydride $\left(0.05 \mathrm{mg} \mathrm{mL}^{-1}\right.$ for characterization and $0.4 \mathrm{mg} \mathrm{mL}^{-1}$ for high loads of enzyme) added at the beginning of the immobilization.}

\section{Immobilization of P450 BM3 onto AMINO-agarose support}

For AMINO-agarose, $50 \mathrm{mmol} \mathrm{L}^{-1}$ sodium phosphate buffer $(\mathrm{pH} \mathrm{6})$ was used to dissolve the enzyme and mix it with the support. The enzyme was left to ionically adsorb onto the support for $0.5-1 \mathrm{~h}$. After that, a $200 \mathrm{mmol} \mathrm{L}^{-1}$ stock solution of $\mathrm{N}$-(3-dimethylaminopropyl)- $\mathrm{N}^{\prime}$-ethylcarbodiimide (EDC) was prepared dissolving it in $50 \mathrm{mmol} \mathrm{L}^{-1}$ phosphate buffer and adjusting to $\mathrm{pH} 6$ with $\mathrm{HCl}$. It was then added at different concentrations and incubated for $30 \mathrm{~min}$. to activate the carboxylic groups and promote the covalent binding. The concentration of EDC was optimized in the characterization phase $(1,2,3,4,5,10,15$, $\left.20 \mathrm{mmol} \mathrm{L}^{-1}\right)$ and also when using high loads of enzyme $(3,6,12$, $\left.30,60 \mathrm{mmol} \mathrm{L}^{-1}\right)$. Finally, $0.5 \mathrm{~mol} \mathrm{~L}^{-1} \mathrm{NaCl}$ was introduced to desorb all the protein attached non-covalently. The immobilization was carried out at $25^{\circ} \mathrm{C}$ with mild agitation.

\section{Co-immobilization of P450 BM3 and GDH in AMINO-agarose and epoxy-agarose-UAB}

The conditions in which immobilizations were carried out were exactly the same as previously described for P450 BM3 for AMINO-agarose and epoxy-agarose-UAB. The activity of the GDH present in the lysate was also monitored in this stage together with the P450 BM3. Retained activities and immobilization yields were obtained for GDH and P450 BM3.

\section{Co-immobilization of P450 and GDH into polyvinyl alcohol lenses (Lentikats ${ }^{\circledR}$ )}

Co-immobilization of GDH and P450 BM3 by entrapment was carried out using an organic polymer commercialized as Lentikats ${ }^{\circledR}$. The solid mixture was heated to $95^{\circ} \mathrm{C}$ until it turned into a transparent liquid. Then it was cooled down to $40^{\circ} \mathrm{C}$ and $8 \mathrm{~mL}$ of the polymer were mixed with $2 \mathrm{~mL}$ of a suspension containing the desired amount of biocatalyst. Afterwards the mixture was poured on a petri dish and the lenses were printed using the LentiPrinter ${ }^{\circledR}$. The resulting plates were left to dry at $25^{\circ} \mathrm{C}$ for $1 \mathrm{~h}$ until they lost $80 \%$ of their weight approximately. Once printed, the support adopted a lentil-like shape of 1-2 mm diameter and $200-300 \mu \mathrm{m}$ wide where the proteins were entrapped inside.

\section{Re-usability of the biocatalyst for the hydroxylation of sodium laureate}

The utilization of the immobilized enzymes in repeated reaction cycles was studied following the consumption of sodium laurate. The reactor $\left(\mathrm{V}_{\mathrm{T}}=5 \mathrm{~mL}\right)$ contained $1.53 \mathrm{mmol} \mathrm{L}^{-1}$ sodium laurate, $0.2 \mathrm{mmol} \mathrm{L}^{-1} \mathrm{NADP}^{+}$and $12.5 \mathrm{mmol} \mathrm{L}^{-1} \mathrm{D}$-glucose. All dissolved in $50 \mathrm{mmol} \mathrm{L}^{-1}$ sodium phosphate buffer $\mathrm{pH}$ 7.5. The enzyme added was the minimum necessary to convert at least $90 \%$ of the initial substrate in $1 \mathrm{~h}$. The reactors used were purchased from MultiSynTech (Witten, Germany) and consisted of $10 \mathrm{~mL}$ plastic vessels with a porous plate at the bottom. It allowed the extraction of the whole reactor liquid content by filtering with this same porous plate without losing any fraction of the immobilized derivative. The reaction took place at $25^{\circ} \mathrm{C}$ and $1000 \mathrm{rpm}$ using a Multi-Therm H5000-HC-E thermo-shaker (Benchmark Scientific Inc., Sayreville, $\mathrm{NJ}$, USA). After each cycle, the immobilized enzymes were washed twice with sodium phosphate buffer $50 \mathrm{mmol} \mathrm{L}^{-1} \mathrm{pH} 7.5$ then new reaction medium was added and substrate conversion was quantified. Experiments were carried out in duplicate.

\section{GC-FID analysis of sodium laurate}

Samples containing sodium laurate and its products were analysed using a 7890A gas chromatograph (Agilent Technologies, USA) equipped with a HP-INNOWAX $19095 \mathrm{~N}-123$ column (30 m, $0.53 \mathrm{~mm}, 1 \mu \mathrm{m}$, Agilent Technologies). Reaction samples were filtered $(\varnothing 0.22 \mu \mathrm{m})$ and $50 \mu \mathrm{L}$ of hexanoic acid $\left(2.8 \mathrm{mg} \mathrm{mL}^{-1}\right)$, that served as internal standard, were added to $300 \mu \mathrm{L}$ of sample. The column temperature started at $150^{\circ} \mathrm{C}$, increased to $240^{\circ} \mathrm{C}$ at $24^{\circ} \mathrm{C} \mathrm{min}^{-1}$, and was held at final temperature for $11 \mathrm{~min}$. The injector temperature was kept at $300^{\circ} \mathrm{C}$; for the flame ionization detector, the temperature was $320^{\circ} \mathrm{C}$. Helium was used as carrier gas at a flow rate of $8 \mathrm{~mL} \mathrm{~min}{ }^{-1}$. All analyses were carried out in duplicate. 


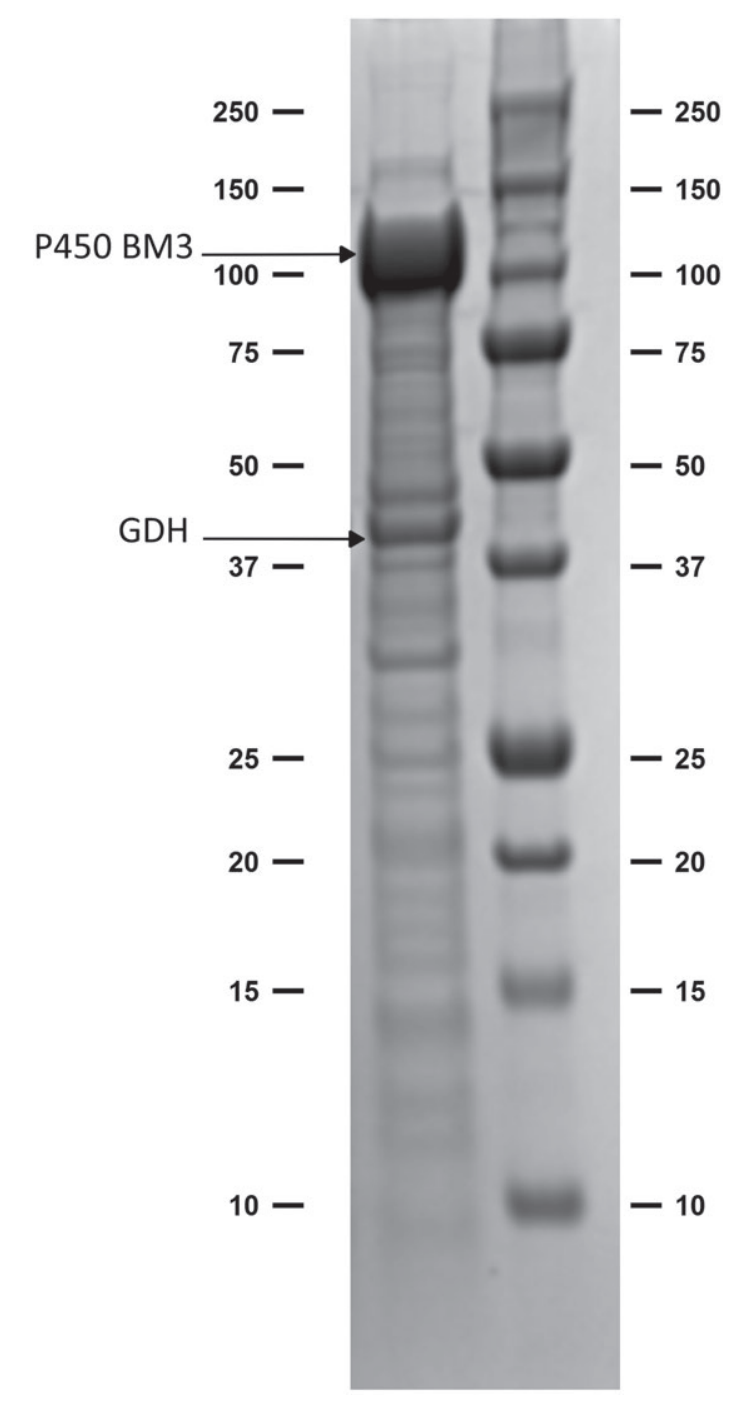

Figure 2. SDS-PAGE gel containing a lysate co-expressing P450 BM3 and GDH (left lane) and a molecular weight standard Bio-Rad Precision Plus (right lane). Numbers on both sides represent the molecular weight of the protein bands $(\mathrm{kDa})$.

\section{RESULTS AND DISCUSSION}

\section{Characterization of the $E$. coli lysate containing P450 BM3 and GDH}

As already mentioned, P450s are enzymes that require a cofactor to perform the redox reactions they catalyse. One of the strategies widely used for overcoming the disadvantages of co-factor dependency is the use of an enzyme-coupled reaction for the regeneration of the expensive NADPH. In this work, GDH (EC 1.1.1.47) from the archaea Thermoplasma acidophilum was used as NADPH-recycling enzyme using glucose as sacrificial substrate (Fig. 1). This robust and stable tetrameric protein is reported to be an efficient enzyme for NADPH regeneration. ${ }^{34,35,41}$

In the present work, GDH was co-expressed with P450 BM3 in E. coli and both enzymes were present in the cell lysates utilized.

The characterization of the lysate was performed regarding protein content, enzyme content (SDS-PAGE, Fig. 2), activity and P450 BM3 active form concentration and the results are shown in Table 1.

The P450 BM3 was expressed at a higher level than the GDH, however, under the conditions in which the activity tests were performed, GDH gave higher specific activity. Table 1, also shows the correlation between activity units (Us) and concentration (nmols) of active enzyme; for the P450 BM3 case, $2.85 \mathrm{U} \mathrm{nmol}^{-1}$.

\section{Screening of supports for the immobilization of P450 BM3 - Purolite ${ }^{\circledR}$}

The main objective of the present work was to obtain a bi-functional self-sufficient oxidative biocatalyst by co-immobilization of P450 BM3 and GDH. To accomplish this, supports and immobilization conditions that were found to be most suitable for the P450 BM3 enzyme were prioritized, since cytochrome is the key enzyme performing the target reaction and it has been described as an unfavourable enzyme for immobilizing. GDH, on the contrary, has been described as a robust and more stable enzyme so difficulties in its immobilization were not anticipated. ${ }^{41}$ In fact, successful immobilization of GDH on different kinds of support has been reported by several authors. ${ }^{42}$ The results obtained for P450 BM3 immobilization, the materials tested and its features are summarized in Table 2 . The supports purchased in the screening kits encompass a range of different particle sizes (45 to $710 \mu \mathrm{m}$ ), matrices (methacrylate, styrene and agarose), functional groups (amino, epoxy and aldehyde), enzyme-support interaction (covalent binding or hydrophobic adsorption) and linker lengths (2 to 18 carbon atoms). All of these properties have been identified as critical for successful enzyme immobilization. ${ }^{12}$

As shown in Table 2, the immobilization yields obtained were higher than $90 \%$ in all cases, except for the supports that interact with the enzyme by hydrophobic adsorption: ECR1061M and ECR1030M. In both cases the immobilization yields only reached $21 \pm 6 \%$ and $33 \pm 1 \%$ respectively. On the other hand, no retained activities or very low values $(<20 \%)$ were observed in all tested supports, except for Praesto 45, 65 and 90, all epoxy-agarose supports (Fig. 3(A)). According to the titration performed, Praesto 45, 65 and 90 contained an epoxide concentration of 9,6 and $8 \mu \mathrm{mol}$ per gram of support respectively and resulted in retained activities of $60-68 \%$ after $4 \mathrm{~h}$ incubation. The maximum loading capacities of these epoxy-agarose resins ranged from 18 to $20 \mathrm{U} \mathrm{g}^{-1}$ and 7 to $8 \mathrm{mg}$ protein $\mathrm{g}^{-1}$ of support. The immobilization profiles were very similar among the three supports and they did not show any significant correlation with the particle size or the initial epoxide concentration (Fig. 3(A)).

Regarding the methacrylate and styrene matrices, even though different ionic strengths and $\mathrm{pH}$ values were assessed, none of the tested supports showed retained activities above $20 \%$. P450 BM3 had adhered to the matrices in most cases, but did not remain active. Two methacrylate-based materials harbouring amino groups on six carbon chain linkers (ECR8409F and the ECR8415F) gave retained activities of $24 \pm 4 \%$ and $22 \pm 3 \%$ respectively when the enzyme was adsorbed onto the resins solely by ionic interactions, however once carbodiimide was added, to promote covalent bond formation, the activity was reduced to $6 \pm 3 \%$ and $18 \pm 1 \%$ respectively. Furthermore, following the supplier's protocol, the four amino methacrylate based supports were further functionalized with glutaraldehyde prior to enzyme binding, but none resulted in successful immobilization either.

It should also be mentioned that methacrylic matrices with the same functional groups as the epoxy-agarose support (ECR8204F, ECR8215F and ECR8285) did not lead to actively immobilized enzyme, as can be seen by the low retained activities obtained $(0 \%$, $2 \pm 1 \%$ and $3 \pm 2 \%$ respectively). These results could indicate that 
Table 1. Characterization of the cell-free extract containing P450 BM3 and glucose dehydrogenase

\begin{tabular}{|c|c|c|c|c|c|}
\hline Enzyme & $\begin{array}{c}\text { [Protein] } \\
\text { (mg protein/ } \\
\text { mL lysate) }\end{array}$ & $\begin{array}{c}\text { Specific } \\
\text { activity (U/mg } \\
\text { protein) }\end{array}$ & $\begin{array}{c}\text { Enzyme }^{\mathrm{a}} \\
\text { (mg enzyme/ } \\
\text { mg protein) }\end{array}$ & $\begin{array}{c}\text { [Enzyme] } \\
\text { (mg enzyme/ } \\
\text { mL lysate) }\end{array}$ & $\begin{array}{c}\text { P450 BM3 } \\
\text { active form } \\
\text { concentration } \\
\left(\mu \mathrm{mol} \mathrm{L}^{-1}\right)\end{array}$ \\
\hline P450 BM3 & $45.4 \pm 0.8$ & $2.8 \pm 0.6$ & $0.52 \pm 0.01$ & $23.8 \pm 0.6$ & $44.9 \pm 2.1$ \\
\hline $\mathrm{GDH}$ & & $3.6 \pm 0.4$ & $0.14 \pm 0.01$ & $6.64 \pm 0.16$ & - \\
\hline
\end{tabular}

Table 2. Main characteristics of the matrices tested and their results regarding immobilization and retained activity of P450 BM3

\begin{tabular}{|c|c|c|c|c|c|c|c|}
\hline Code & $\begin{array}{c}\text { Functional group } \\
\text { (Linker) }\end{array}$ & Matrix & Interaction & Pore diameter $(\AA ̊)$ & $\begin{array}{l}\text { Particle } \\
\text { size }(\mu \mathrm{m})\end{array}$ & $\begin{array}{l}\text { Immobilization } \\
\text { yield (\%) }\end{array}$ & $\begin{array}{l}\text { Retained } \\
\text { activity (\%) }\end{array}$ \\
\hline ECR8204F & Epoxy & Methacrylate & Covalent & $300-600$ & $150-300$ & $92 \pm 4$ & 0 \\
\hline ECR8215F & Epoxy & Methacrylate & Covalent & $1200-1800$ & $150-300$ & $99 \pm 1$ & $2 \pm 1$ \\
\hline ECR8309F & Amino $(C 2)$ & Methacrylate & Ionic/Covalent & $600-1200$ & $150-300$ & $95 \pm 5$ & $3 \pm 2$ \\
\hline ECR8315F & Amino (C2) & Methacrylate & Ionic/Covalent & $1200-1800$ & $150-300$ & $97 \pm 2$ & $4 \pm 2$ \\
\hline ECR8409F & Amino (C6) & Methacrylate & Ionic/Covalent & $600-1200$ & $150-300$ & 100 & $6 \pm 3$ \\
\hline ECR8415F & Amino (C6) & Methacrylate & Ionic/Covalent & $1200-1800$ & $150-300$ & $98 \pm 1$ & $18 \pm 1$ \\
\hline ECR8285 & Epoxy (C4) & Methacrylate & Ionic/Covalent & $400-600$ & $300-710$ & 100 & $3 \pm 2$ \\
\hline ECR8806F & None (C18) & Methacrylate & Hydrophobic & $500-700$ & $150-300$ & $93 \pm 2$ & 0 \\
\hline ECR1061M & None & Styrene/Methacrylic & Hydrophobic & $600-750$ & $300-710$ & $21 \pm 6$ & 0 \\
\hline ECR1030M & None & Styrene/Methacrylic & Hydrophobic & $200-300$ & $300-710$ & $33 \pm 1$ & $7 \pm 14$ \\
\hline Praesto 45 & Epoxy & Agarose & Covalent & ND & 45 & $92 \pm 6$ & $63 \pm 1$ \\
\hline Praesto 65 & Epoxy & Agarose & Covalent & ND & 65 & $95 \pm 1$ & $68 \pm 3$ \\
\hline Praesto 90 & Epoxy & Agarose & Covalent & ND & 90 & $95 \pm 1$ & $60 \pm 11$ \\
\hline
\end{tabular}

for P450 immobilization the hydrophilicity of the matrix is a key factor. The higher hydrophobicity of the methacrylate/styrene matrices, together with the flexible nature of the enzyme and the presence of two active sites, are probably the causes of the deactivation of the biocatalyst. ${ }^{43}$ This hypothesis would also be in accordance with the low immobilization yields and retained activities obtained with the styrene matrices (ECR1061M and ECR1030M). The immobilization mechanism of these matrices is also based on hydrophobic adsorption and both the immobilization yield and retained activity are low. Other authors have also reported unsuccessful attempts to immobilize P450s by hydrophobic adsorption. Maurer et al. attempted to immobilize the P450 BM3 on hydrophobic supports such as EP100, MP1000, phenylsepharose, octylsepharose and nutylsepharose but none of them presented final retained activity. $^{13}$

Taking into account the results obtained in the screening which showed a strong effect of the hydrophilicity of the matrix on P450 immobilization, agarose was chosen to perform further studies.

\section{Immobilization of P450 BM3 onto different functionalized agaroses}

In addition to the epoxy resins already tested (Praesto 45, 65 and 90), two other agarose matrices with free epoxy groups and different epoxide concentrations were studied: a commercial lyophilized epoxy-agarose resin from Sigma-Aldrich ${ }^{\circledR}$ (epoxy-agarose-SIGMA) and an in-house functionalized agarose resin (epoxy-agarose-UAB) prepared as shown in the experimental section. In addition, an agarose based matrices containing aldehyde (GLYOXYL-agarose) and primary amine (AMINO-agarose) functional groups were tested.

The epoxy-agarose-SIGMA resin, according to the titration performed, contained an epoxide concentration of $110 \pm 7 \mu \mathrm{mol} \mathrm{g}^{-1}$ of support and gave an immobilization yield greater than $95 \%$ after $0.5 \mathrm{~h}$ (Fig. 3(B)). However, a rapid decrease in activity of the suspended biocatalyst was noted during the immobilization procedure, indicating strong deactivation of the enzyme after immobilization. Thus, after just half an hour, low retained activities $(35 \pm 8 \%)$ were observed from this support. These results could indicate that the utilization of an epoxy-agarose with high epoxide concentration, such as the epoxy-agarose-SIGMA, results in a progressive loss of activity over time due to the multipoint attachment of the enzyme to the support. ${ }^{44}$ The explanation can be found in the reactivity of the epoxy groups which differs over time: first, reacting with the amines present on the surface of the enzyme and second reacting with the carboxyl and thiol groups. ${ }^{45}$ At the end, if the incubation time is long enough, the protein can be attached at too many points and lose its whole catalytic activity. This issue can be stopped by adding a blocking agent that removes the unreacted epoxy groups once the protein is immobilized. In Fig. 3(B), $\beta$-mercaptoethanol $\left(0.2 \mathrm{~mol} \mathrm{~L}^{-1}\right.$ final concentration) was added after $0.5 \mathrm{~h}$ and the suspension was incubated for $3.5 \mathrm{~h}$ at $25^{\circ} \mathrm{C}$. No significant loss of activity was observed during this period which validates the hypothesis of multipoint attachment as the main reason for enzyme deactivation. However, due to its elevated cost $\left(118 € \mathrm{~g}^{-1}\right)$ and low retained activities, compared with the 


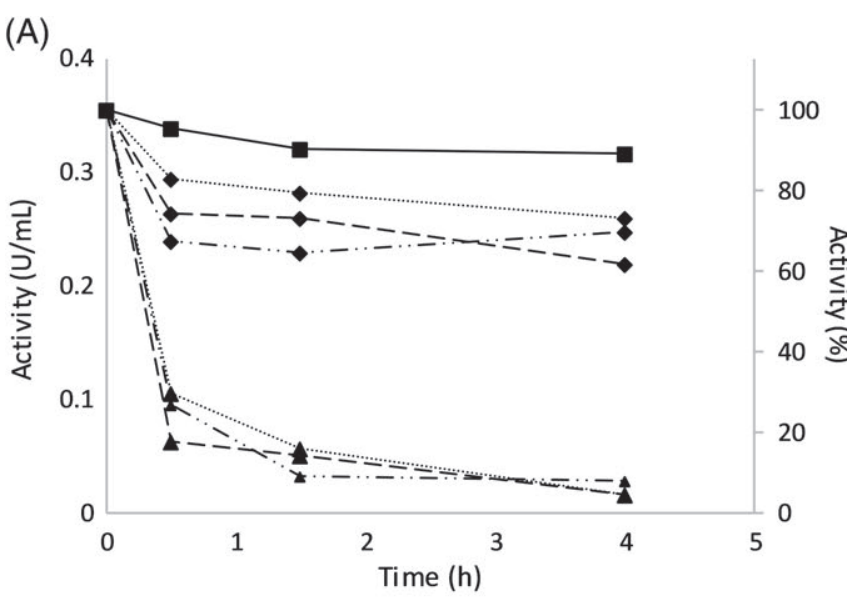

(B)

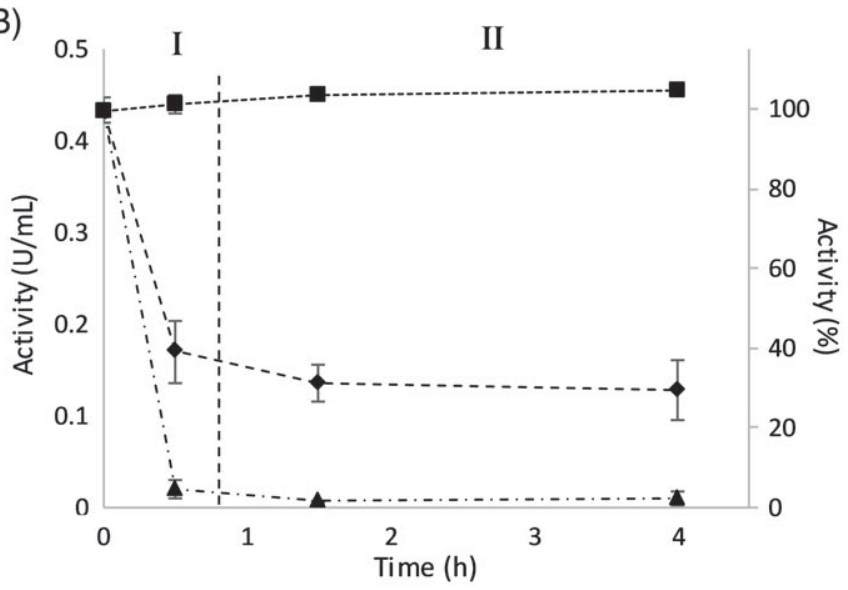

(C)

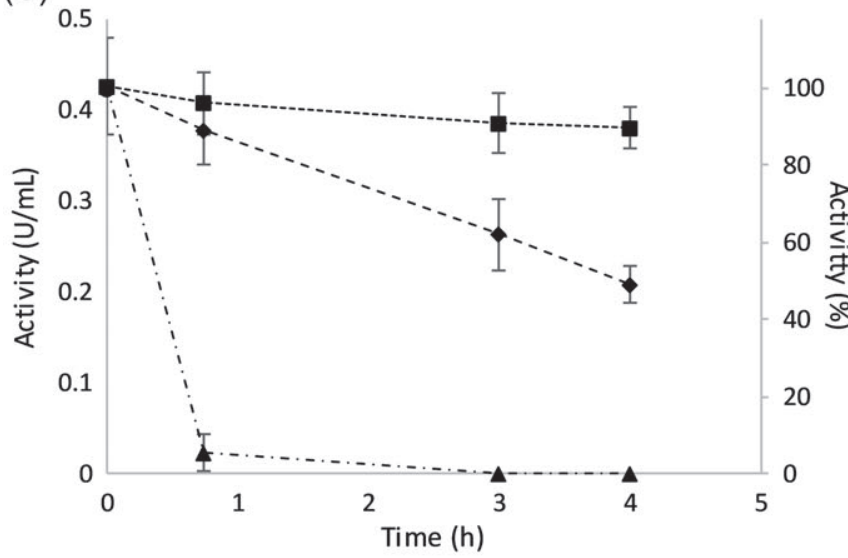

(D)

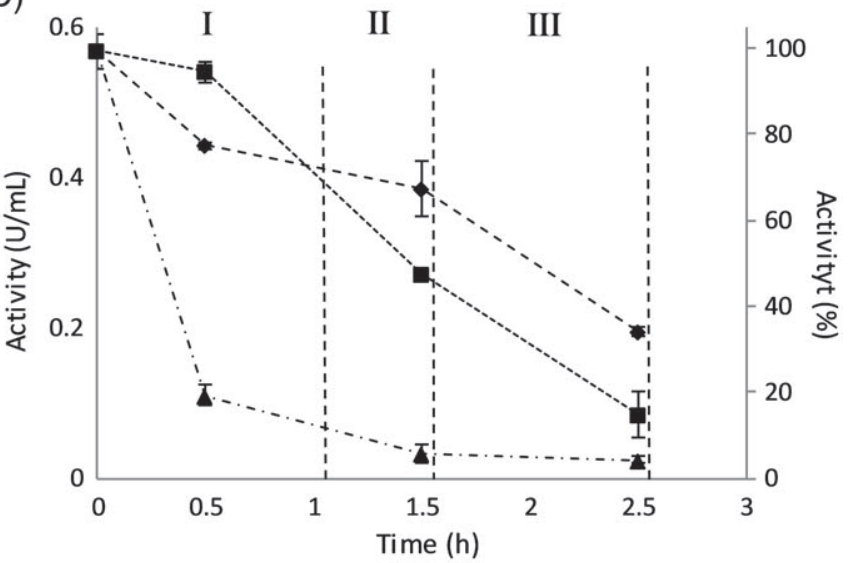

Figure 3. P450 BM3 immobilization onto: (A) Praesto 45 [discontinued line (-----)], 65 [dotted line (.....)] and 90 [combined dotted and discontinued line (-....-)] [sodium phosphate buffer $1 \mathrm{~mol} \mathrm{~L}^{-1}, \mathrm{pH}$ 8]; (B) epoxy-agarose-Sigma [sodium phosphate buffer 1 mol $\mathrm{L}^{-1}$, $\mathrm{pH}$ 8]; (I) the enzyme is bound to the support (II) $\beta$-mercaptoethanol $0.2 \mathrm{~mol} \mathrm{~L}^{-1}$ final concentration is added to eliminate the unreacted epoxy groups; (C) epoxy-agarose-UAB [sodium phosphate buffer $1 \mathrm{~mol} \mathrm{~L}^{-1}, \mathrm{pH}$ 8]; and (D) AMINO-agarose [sodium phosphate buffer $0.05 \mathrm{~mol} \mathrm{~L}^{-1}, \mathrm{pH}$ ]; (I) adsorption of the enzyme to the support (II) incubation with certain amount of carbodiimide (EDC) (III) incubation with $0.5 \mathrm{M} \mathrm{NaCl}$ and desorption of the unattached protein. The activity offered always ranged from 3.5 to $6 \mathrm{U} \mathrm{g}^{-1}$ of resin. The activities of a blank (squares), the supernatant (rhombus) and the suspension (triangle) were continuously analysed. Error bars correspond to standard deviation $(n=2)$.

Praesto supports, the epoxy-agarose-SIGMA was discarded from further studies.

On the other hand, the epoxy-agarose-UAB displayed an epoxide concentration of $30 \pm 3 \mu \mathrm{mol} \mathrm{g}^{-1}$ of support and gave more than $95 \%$ immobilization yield and $83 \pm 8 \%$ retained activity after $0.5 \mathrm{~h}$ (Fig. $3(\mathrm{C})$ ), with a maximum loading capacity of $30 \pm 2 \mathrm{U} \mathrm{g}^{-1}$ of support $\left(7.5 \pm 0.8 \mathrm{mg}\right.$ protein $\mathrm{g}^{-1}$ of support). A decrease in retained activity can also be seen, reaching $50 \pm 5 \%$ after $4 \mathrm{~h}$ of incubation probably due to the excessive number of covalent bindings. In this case, as well as for Praesto supports (Fig. 3(A)), the agarose contains a lower epoxide concentration compared with epoxy-agarose-SIGMA. Therefore, the activity loss due to multipoint attachment is lower for the epoxy-agarose-UAB or even negligible for the Praesto compared with the epoxy-agarose-SIGMA. Thus, when choosing the right support, a consensus should be found. Higher epoxide concentration may imply higher loading capacity as is seen when comparing Praesto (18 to $20 \mathrm{U} \mathrm{g}^{-1}$ of support) and epoxy-agarose-UAB $\left(30 \pm 2 \mathrm{U} \mathrm{g}^{-1}\right.$ of support); however, at the same time, higher epoxide concentration entails higher deactivation of the enzyme over time as is the case comparing all three epoxy-agaroses: Praesto (32-40\% activity lost), epoxy-agarose-SIGMA (75\% activity lost) and epoxy-agarose-UAB
(50\% activity lost). In this sense, due to the loading capacity, the high retained activities reached and the low cost $\left(2.5 € \mathrm{~g}^{-1}\right)$, the epoxy-agarose-UAB was considered the best candidate for the immobilization of P450 BM3 among epoxy-agaroses. This study represents a deeper insight into the work of Axarli et al. ${ }^{14}$ in the understanding of the immobilization of P450 BM3 on epoxy-agaroses and sets the basis for an optimal process.

As mentioned before, other agarose-based supports with different functional groups were also tested such as GLYOXYL-agarose and AMINO-agarose. The GLYOXYL-agarose (aldehyde activated) immobilization must be pursued in alkali media, ${ }^{46}$ however, P450 $\mathrm{BM} 3$ is not stable above $\mathrm{pH} 8.5$ (data not shown). After screening a range of immobilization $\mathrm{pHs}(6.5-8.5), 7.5$ was the best performing one resulting in $50 \pm 2 \%$ retained activity after $6 \mathrm{~h}$ incubation. For the reduction of the Schiff base formed between the aldehyde of the resin and the amine of the enzyme, two reducing agents were tested: (i) sodium borohydride $\left(1 \mathrm{mg} \mathrm{mL}^{-1}\right)$ which is added at the end of the incubation; and (ii) sodium cyanoborohydride $\left(0.05 \mathrm{mg} \mathrm{mL}^{-1}\right)$ which has slower kinetics and can be added at the beginning of the immobilization. Sodium borohydride resulted in complete deactivation of the enzyme while the sodium cyanoborohydride strategy resulted in $36 \pm 0.1 \%$ of 
retained activity. Thus, sodium cyanoborohydride was selected as the most suitable reducing agent. Regarding the studies on maximum loading capacity, the values previously obtained in the characterization ( $36 \pm 0.1 \%$ retained activity) at low enzyme loadings were not extrapolated and a major inactivation occurred. This support has proved suitable for the immobilization of P450 BM3, nevertheless, since the covalent immobilization using high loading was not successful, it was discarded from further studies.

Regarding AMINO-agarose, as for the other tested supports functionalized by amino groups (i.e. ECR8309F, ECR8315F, ECR8409F and ECR8415F) the immobilization is based on a three-stage process. In the first stage, the enzyme is adsorbed onto the support surface by ionic interaction of the amino groups of the support and the carboxyl groups of the enzyme, thus an ionic adsorption occurs. In the second stage, carbodiimide is added to the medium aiming to activate the carboxyl groups present on the enzyme making covalent bonding possible. Solutions with high ionic strength such as sodium chloride $\left(0.5 \mathrm{~mol} \mathrm{~L}^{-1}\right)$ can be finally added to desorb all the protein attached non-covalently (third stage). Ionic adsorption on AMINO-agarose was performed at pH 6 and gave $58 \pm 6 \%$ retained activity (Fig. $3(\mathrm{D})$ phase I). This value was $2.4-2.6$ fold higher than the retained activities obtained during the ionic adsorption for the methacrylate based materials ECR8409F and ECR8415F harbouring the same functional group ( $24 \pm 4 \%$ and $22 \pm 3 \%$ ), as previously discussed. The maximum loading capacity achieved was $112 \pm 2 \mathrm{Ug}^{-1}$ of support ( $50 \pm 4 \mathrm{mg}$ protein $\mathrm{g}^{-1}$ of support) which represents the highest value among all the resins tested. Covalent binding of the amine and the carboxyl groups was carried out by adding EDC following ionic adsorption phase (Fig. 3(D) phase II). Since carbodiimide can lead to enzyme deactivation, different concentrations and incubation times were studied to determine the optimal conditions for the covalent binding phase. These studies showed optimal values of $3 \mathrm{mmol} \mathrm{L}^{-1}$ EDC and $30 \mathrm{~min}$ reaction time respectively. Following covalent attachment, the biocatalyst was incubated with $0.5 \mathrm{~mol} \mathrm{~L}^{-1} \mathrm{NaCl}$ for $2 \mathrm{~h}$ (Fig. 3(D), phase III) in order to increase the ionic strength of the media and release all the protein not adhered covalently. $28 \pm 1 \%$ of the initial activity offered was covalently bound to the agarose, which represents $30 \%$ less activity than the value obtained for the ionic adsorption phase (Fig. 3(D), phase I). On the other hand, compared with the methacrylate-based supports, the retained activity was 4.7-fold and 1.6-fold higher than that obtained with ECR8409F and ECR8415F, respectively. Regarding the maximum load, $53 \pm 2 \mathrm{U} \mathrm{g}^{-1}$ of resin was reached ( $47 \pm 3 \mathrm{mg}$ protein $\mathrm{g}^{-1}$ of support), representing a $52 \%$ decrease in immobilized activity compared with that obtained by ionic adsorption, likely due to enzyme deactivation caused by the carbodiimide. When testing for the maximum loading capacity the concentration of EDC was further optimized since more enzyme was added (Fig. 4). It resulted in an optimal concentration between 6 and $12 \mathrm{mmol} \mathrm{L}^{-1}$. This second value was chosen due to the higher immobilization yield that it entailed. This support represents a step forward in comparison with the other tested agaroses and it is the first work reporting a successful covalent immobilization of P450 BM3 in an amino-based matrix.

Other authors have worked with P450s and agarose based matrices before. In 1988 King et al. obtained 100\% immobilization yield and $66 \%$ retained activity using a cyanogen bormide-sepharose $4 \mathrm{BCL}$ and a P450 from Saccharomyces cerevisiae. Another example is the aforementioned case of Axarli et al., who immobilized

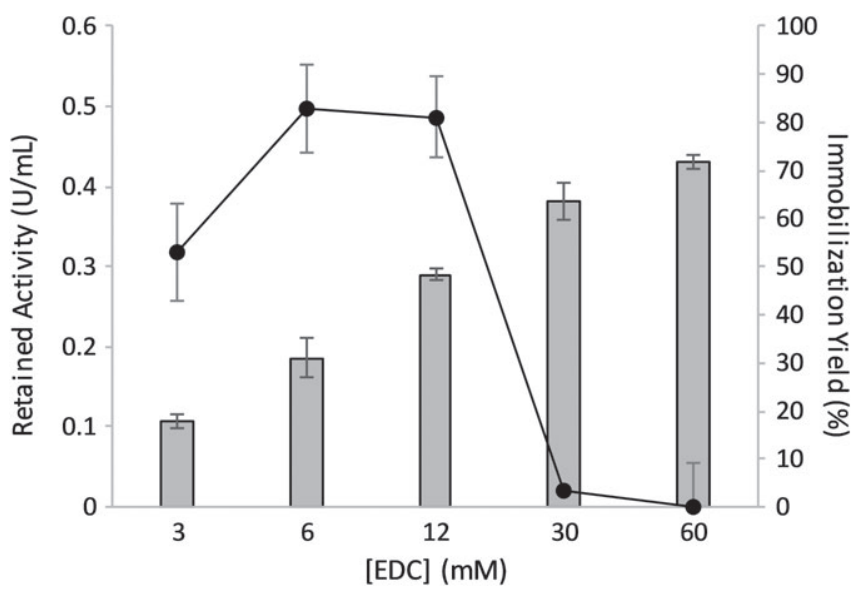

Figure 4. Optimization of the EDC concentration in AMINO-agarose experiments using high loads. The immobilization was carried out using sodium phosphate buffer $50 \mathrm{mmol} \mathrm{L}^{-1} \mathrm{pH} 6$ and offering $92 \mathrm{U} \mathrm{g}^{-1}$ of resin. Retained activity (black dots) and immobilization yield (grey bars) are represented. Error bars correspond to standard deviation $(n=2)$.

the P450 BM3 on epoxy-agarose and obtained $81 \%$ retained activity. ${ }^{14}$

\section{Co-immobilization of P450 BM3 and glucose dehydrogenase}

As has already been mentioned, for co-immobilization of both $\mathrm{GDH}$ and P450 BM3, it was decided to prioritize the supports and immobilization conditions that were found to be suitable for P450 $B M 3$, i.e. epoxy-agarose-UAB and AMINO-agarose.

The immobilization of GDH using epoxy-agarose-UAB resulted in poor affinity of the protein for the support with immobilization yields below $20 \%$. However, of the enzyme that did adhere, a slight over-activation was observed compared with the same quantity of free enzyme. At the end of the incubation ( $4 \mathrm{~h})$, retained activity of $20 \pm 5 \%$ and a maximum loading capacity of $3 \pm 0.1 \mathrm{Ug}^{-1}$ of support were achieved. Since the conditions were exactly the same as reported above for P450 BM3, the activity for the cytochrome was comparable and resulted in $50 \pm 5 \%$ retained activity and $30 \pm 2 \mathrm{U} \mathrm{g}^{-1}\left(7.5 \pm 0.8 \mathrm{mg}\right.$ protein $\mathrm{g}^{-1}$ of support).

With AMINO-agarose, GDH presented high affinity for the support and it also showed an over-activation effect when adhered to the matrix. It had better tolerance of the presence of EDC compared with $\mathrm{P} 450 \mathrm{BM} 3$, with $10 \mathrm{mmol} \mathrm{L}^{-1}$ being the optimal concentration for this enzyme ( $57 \pm 2 \%$ retained activity) in the characterization phase. Co-immobilization of both enzymes, initially using a low carbodiimide concentration of $3 \mathrm{mmol} \mathrm{\textrm {L } ^ { - 1 }}$, resulted in $25 \pm 4 \%$ retained activity for $\mathrm{GDH}$ and $28 \pm 1 \%$ for P450 BM3. Using a higher loading of EDC $\left(12 \mathrm{mmol} \mathrm{L}^{-1}\right)$ resulted in a loading capacity of $18 \pm 1 \mathrm{Ug}^{-1}$ of support for GDH and $53 \pm 2 \mathrm{U} \mathrm{g}^{-1}$ of support for P450 BM3. In summary, a self-sufficient oxidative biocatalyst was obtained.

There are several examples in the literature of the immobilization of GHD. ${ }^{42}$ Regarding the immobilization on agarose based matrices, Anwar et al. immobilized a baker's yeast GDH on cyanogen bromide-sepharose obtaining a retained activity of $3 \% .{ }^{47}$ Persson et al. purified a GDH from Bacillus subtilis by immobilizing it on thiopropyl-sepharose and recovered up to $65 \%$ of the initial activity. ${ }^{48}$ However, as far as the authors know, this is the first time that GDH has been covalently co-immobilized with P450 BM3. 


\section{Co-immobilization of P450 BM3 and GDH into polyvinyl} alcohol particles - entrapment

Finally, as an alternative to immobilization by adsorption or by covalent attachment, an entrapment strategy was also investigated for co-immobilization. Both P450 BM3 and GDH were successfully embedded into Lentikats ${ }^{\circledR}$ (polyvinyl matrix) as described in the experimental section. The analysis undertaken, showed maximum retained activities of $100 \pm 0.1 \%$ for both P450 BM3 and GDH.

In the sense of the loading capacity employed, the activity and concentration of protein in the polymer was $1.8 \pm 0.2 \mathrm{U} \mathrm{g}^{-1}$ of P450 $\mathrm{BM} 3,0.8 \pm 0.1 \mathrm{U} \mathrm{g}^{-1}$ of $\mathrm{GDH}$ and $1.1 \pm 0.1 \mathrm{mg}^{2}$ protein $\mathrm{g}^{-1}$ of support respectively. It was not further increased due to operational issues. The capacity is limited by an aggregation effect observed when charging high concentrations of lysate with which the lenses form a compact mass that cannot be used in our reactions. This is a serious drawback when looking to industrial feasibility because the enzyme must be previously purified or the specific activity of the support would remain too low. ${ }^{31}$ However, since the immobilization had been successful, albeit with low enzyme loading, and it is the first work that reports a successful entrapment of both P450 $\mathrm{BM} 3$ and GDH in Lentikats ${ }^{\circledR}$, it was decided to continue working with this immobilized derivative.

\section{Reusability of the biocatalyst using sodium laurate as substrate}

From all the supports tested, AMINO-agarose, epoxy-agarose-UAB and Lentikats ${ }^{\circledR}$ were considered good candidates to be potential carriers in bio-catalysis applications. It is well-known that uncoupling effects on $\mathrm{P} 450$ s produce reactive oxygen species that inactivate the enzyme (uncoupling). ${ }^{49}$ This handicap is less relevant when working with native substrates such as sodium laureate and so this substrate was used as a model for studying the reusability of the self-sufficient biocatalyst. First, the coupling efficiency of P450 towards this substrate was determined and then reusability studies were performed using the self-sufficient P450/GDH biocatalysts obtained with the aforementioned carriers.

Reactions using sodium laureate $\left(1.3 \mathrm{mmol} \mathrm{L}^{-1}\right)$ and NADPH ( $\left.0.2 \mathrm{mmo} \mathrm{L}^{-1}\right)$ were performed, monitoring and comparing substrates consumption by means of GC-FID. A coupling efficiency of $90.4 \pm 8.3 \%$ was observed, which means that, $90.4 \%$ of the NADPH consumed was employed for sodium laurate hydroxylation, with the remainder directed towards uncoupled reactions. This substrate was considered adequate to assess the operational stability of the enzymes in repeated reaction cycles.

Total turnover number (mols of substrate consumed $/ \mathrm{mols}$ of P450 BM3) (TTN) was chosen as the metric to evaluate the yield of the self-sufficient biocatalyst in comparison with the soluble lysate. To assess it, the immobilized P450 BM3/GDH (epoxy-agarose-UAB, AMINO-agarose and Lentikats $\left.{ }^{\circledR}\right)$ biocatalysts were tested in sodium laurate reaction cycles of $1 \mathrm{~h}$ each utilizing glucose as the sacrificial substrate and the cofactor in its oxidized form $\left(\mathrm{NADP}^{+}\right)$thus forcing the cofactor regeneration to start before the $\mathrm{P} 450$-catalysed reaction. Moreover, $\mathrm{NADP}^{+}$starting concentration was 6.5 -fold lower than the sodium laureate. The amount of P450 BM3 required to convert $>90 \%$ of sodium laurate in $1 \mathrm{~h}$ was found to be $0.18-0.2 \mathrm{U} \mathrm{mL}^{-1}\left(0.063-0.07 \mathrm{nmol} \mathrm{mL}^{-1}\right)$. GDH on the other hand, was always ensured to be present in excess so that it did not limit the hydroxylation reaction. The conversions obtained in each cycle for the immobilized systems are presented in Fig. 5. The TTN for the soluble reaction was $21500 \pm 290$ mols of sodium laurate consumed/mol of $\mathrm{P} 450 \mathrm{BM} 3$ in $1 \mathrm{~h}$ of reaction.
The immobilized derivatives allowed the re-utilization of the self-sufficient biocatalyst boosting the TTN by 2.31 -fold for the epoxy-agarose-UAB, 2.98-fold for AMINO-agarose and 2.3-fold for the enzymes immobilized into Lentikats ${ }^{\circledR}$. As shown in Fig. 5, the conversion dropped in an exponential manner for epoxy-agarose (Fig. 5(A)). On the contrary, with AMINO-agarose and Lentikats ${ }^{\circledR}$ the decay was more linear (Fig. 5(B) and (C)). At the end, all three derivatives could be re-used successfully, thus demonstrating significant operational stability.

Some examples can be found in the literature about the reusability of P450s. Lee et al. immobilized a phasin fused P450 BM3 and re-used it four times with no loss of activity. ${ }^{17}$ Zhao et al. were able to use a P450 BM3 mutein together with catalase in 10 batch cycles with conversions up to $80 \% .{ }^{16}$ Regarding $\mathrm{GDH}$, different studies of re-usability have been reported. A recent example, Petrovicová et al. co-immobilized a ketoreductase and a GDH from Bacillus megaterium in polyvinyl alcohol particles and were able to use the derivate 18 times with minimal loss of activity. ${ }^{50}$

\section{CONCLUSIONS}

P450 BM3 has gained much interest in recent years in biocatalysis for its oxy-functionalization characteristics, although, the implementation of this enzyme in industrial processes has lacked optimal metrics. Operational stability as well as its requirement for $\mathrm{NADPH}$ in stoichiometric amounts have been identified as the main bottlenecks. Aiming to overcome these two main drawbacks, P450 BM3 and GDH have been co-immobilized in the present work to obtain a robust bi-functional self-sufficient biocatalyst.

P450 BM3 and GDH were covalently co-immobilized on epoxy-functionalized agarose and amino-functionalized agarose. Both enzymes were also successfully co-immobilized by entrapment in a polyvinyl alcohol/polyethylen-glycol matrix named Lentikats ${ }^{\circledR}$. From the five epoxy-agaroses tested, the optimal support (epoxy-agarose-UAB) presented an epoxide concentration of $30 \pm 3 \mu \mathrm{mol} \mathrm{g}^{-1}$ of support and retained activities of $83 \pm 8 \%$ for P450 BM3 and $20 \pm 5 \%$ for GDH. On the other hand, AMINO-agarose showed retained activities of $28 \pm 1 \%$ for P450 and $25 \pm 4 \%$ for GDH. Finally, the entrapment of both enzymes in Lentikats ${ }^{\circledR}$ led to P450 BM3 and GDH co-immobilization maintaining $100 \%$ of the activity initially loaded.

P450 BM3 was also immobilized on aldehyde-functionalized agarose and presented $36 \pm 0.1 \%$ retained activity. However, this support did not allow high enzyme loads required for reaction testing, thus making this support unattractive for further studies.

The operational stability of the obtained bi-functional self-sufficient biocatalysts (epoxy-agarose-UAB, AMINO-agarose and Lentikats $\left.{ }^{\circledR}\right)$ was analysed in terms of re-usability for sodium laureate oxidation. All three derivatives showed successful reuse over five cycles, entailing an increment in the TTN of 2.31-fold for the epoxy-agarose-UAB, 2.98-fold for the AMINO-agarose and 2.3-fold for the Lentikats ${ }^{\circledR}$ compared with the soluble enzymes.

The P450 BM3 wild type served as a model in the immobilization studies in this work. On the other hand, mutated P450 BM3s, usually required for oxidative reactions of non-natural substrates which entail high uncoupling effects, can follow the exact same principles reported here since the surface of the enzyme is usually unaffected. ${ }^{1,5,6,51}$ In this sense, immobilization can be an added value to the process, for these new enzymes, due to the many advantages that it confers. 
(A)

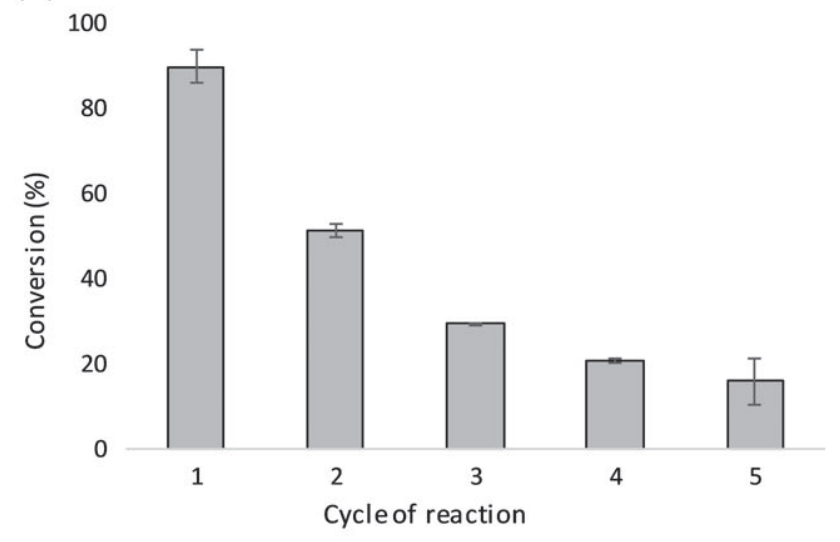

(B)

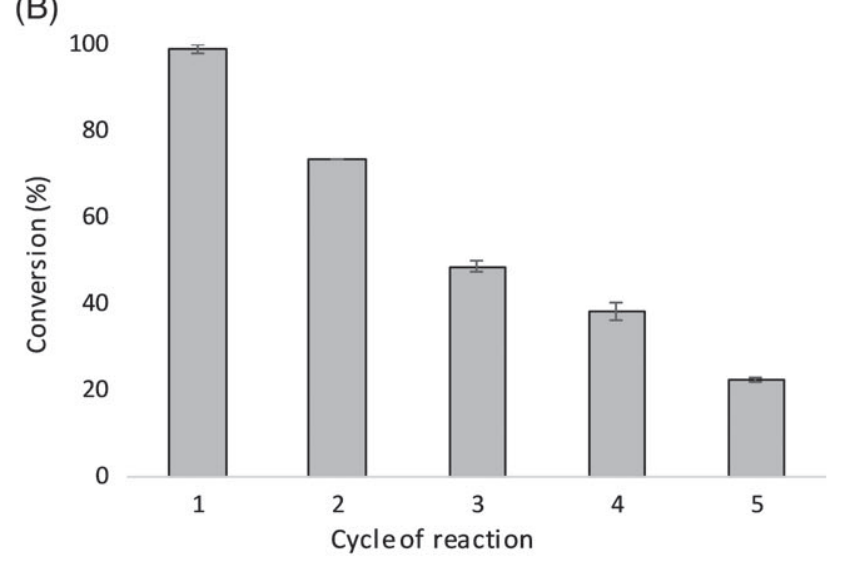

(C)

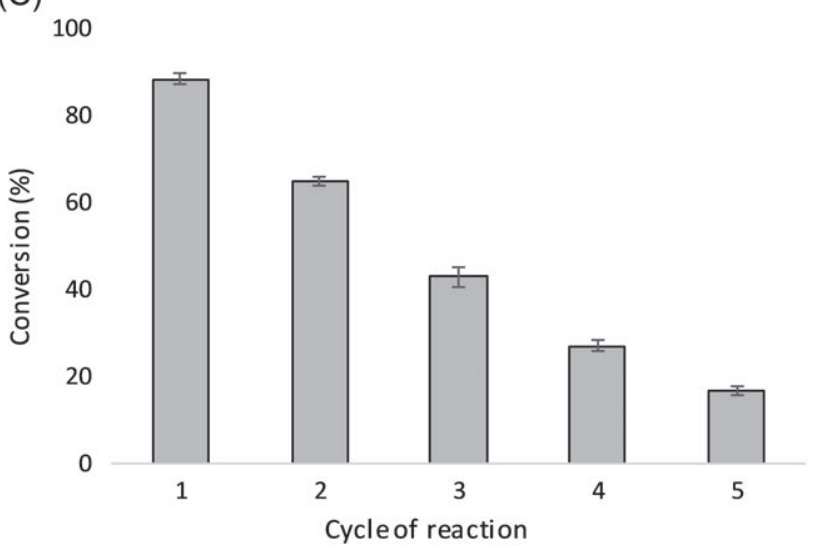

Figure 5. Reaction cycles using both $\mathrm{P} 450 \mathrm{BM} 3$ and GDH immobilized onto: (A) epoxy-agarose-UAB (10 mg of agarose $\mathrm{mL}^{-1}$ ); (B) AMINO-agarose (10 mg of agarose $\left.\mathrm{mL}^{-1}\right)$; and $(C)$ Lentikats ${ }^{\circledR}\left(50 \mathrm{mg}\right.$ of Lentikats $\left.\mathrm{mL}^{-1}\right)$. Reactions were carried on at $5 \mathrm{~mL}$ scale adding $0.18-0.2 \mathrm{U}$ of total activity and using sodium phosphate buffer $50 \mathrm{mmol} \mathrm{L}^{-1} \mathrm{pH} 7.5,1.3 \mathrm{mmol} \mathrm{L}^{-1}$ sodium laurate, $0.2 \mathrm{mmol} \mathrm{L}^{-1} \mathrm{NADP}^{+}, 12.5 \mathrm{mmol} \mathrm{L}^{-1} \mathrm{D}$-glucose, temperature control at $25^{\circ} \mathrm{C}$ and constant $1000 \mathrm{rpm}$ agitation using a multi-therm H5000-HC-E thermos shaker. Error bars correspond to standard deviation $(n=2)$.

\section{ACKNOWLEDGEMENTS}

The research for this work has received funding from the European Union project ROBOX (grant agreement $n^{\circ}$ 635734) under EU's Horizon 2020 Programme Research and Innovation actions H2020-LEIT BIO-2014-1. This document reflects only the author's view and the Agency is not responsible for any use that may be made of the information it contains. The Department of Chemical, Biological and Environmental Engineering of Universitat Autònoma de Barcelona constitutes the Biochemical Engineering Unit of the Reference Network in Biotechnology and the research group 2017 SGR 1462, Generalitat de Catalunya. Authors also thanks COST Action CM 1303-Systems Biocatalysis for financial support and Purolite Life Sciences ${ }^{\circledR}$ for the support given. Jordi Solé also thanks UAB for funding his $\mathrm{PhD}$ grant.

\section{REFERENCES}

1 Urlacher VB and Girhard M, Cytochrome P450 monooxygenases: an update on perspectives for synthetic application. Trends Biotechnol 30:26-36 (2012). 
2 Guengerich FP, Common and uncommon cytochrome P450 reactions related to metabolism and chemical toxicity. Chem Res Toxicol 14:611-650 (2001).

3 Narhi LO and Fulco AJ, Characterization of a catalytically self-sufficient 119,000-Dalton cytochrome P-450 monooxygenase induced by barbiturates in Bacillus megaterium. J Biol Chem 261:7160-7169 (1986).

4 Warman AJ, Roitel O, Neeli R, Girvan HM, Seward HE, Murray SA et al., Flavocytochrome P450 BM3: an update on structure and mechanism of a biotechnologically important enzyme. Biochem Soc Trans 33:747-753 (2005).

5 Whitehouse CJC, Bell SG and Wong L-L, P450 ${ }_{\mathrm{BM}}$ (CYP102A1): connecting the dots. Chem Soc Rev 41:1218-1260 (2012).

6 Bernhardt R and Urlacher VB, Cytochromes P450 as promising catalysts for biotechnological application: chances and limitations. Appl Microbiol Biotechnol 98:6185-6203 (2014).

7 Paddon CJ, Westfall PJ, Pitera DJ, Benjamin K, Fisher K, McPhee D et al., High-level semi-synthetic production of the potent antimalarial artemisinin. Nature 496:528-532 (2013).

8 Kaluzna I, Schmitges T, Straatman H, van Tegelen D, Müller M, Schürmann $\mathrm{M}$ et al., Enabling selective and sustainable P450 oxygenation technology. Production of 4-Hydroxy-??-isophorone on kilogram scale. Org Process Res Dev 20:814-819 (2016).

9 Guzik U and Hupert-kocurek K, Immobilization as a strategy for improving enzyme properties-application to oxidoreductases. Molecules 19:8995-9018 (2014).

10 Tischer W and Wedekind F, Immobilized enzymes: methods and applications. Biocatal Discov Appl 200:95-126 (1999).

11 DiCosimo R, McAuliffe J, Poulose AJ and Bohlmann G, Industrial use of immobilized enzymes. Chem Soc Rev 42:6437-6474 (2013).

12 Santos JCSD, Barbosa O, Ortiz C, Berenguer-Murcia A, Rodrigues RC, Fernandez-Lafuente $\mathrm{R}$ et al., Importance of the support properties for immobilization or purification of enzymes. ChemCatChem 7:2413-2432 (2015)

13 Maurer SC, Schulze $\mathrm{H}$, Schmid RD and Urlacher V, Immobilisation of $\mathrm{P} 450 \mathrm{BM}-3$ and an $\mathrm{NADP}(+)$ cofactor recycling system towards a technical application of heme-containing monooxygenases in fine chemical synthesis. Adv Synth Catal 345:802-810 (2003).

14 Axarli I, Prigipaki A and Labrou NE, Engineering the substrate specificity of cytochrome P450 CYP102A2 by directed evolution: production of an efficient enzyme for bioconversion of fine chemicals. Biomol Eng 22:81-88 (2005).

15 Weber E, Sirim D, Schreiber T, Thomas B, Pleiss J, Hunger M et al., Immobilization of P450 BM-3 monooxygenase on mesoporous molecular sieves with different pore diameters. J Mol Catal B: Enzym 64:29-37 (2010).

16 Zhao L, Güven G, Li Y and Schwaneberg U, First steps towards a $\mathrm{Zn} / \mathrm{Co}$ (III)sep-driven P450 BM3 reactor. Appl Microbiol Biotechnol 91:989-999 (2011).

17 Lee JH, Nam DH, Lee SH, Park JH, Park SJ, Lee SH et al., New platform for cytochrome $\mathrm{P} 450$ reaction combining in situ immobilization on biopolymer. Bioconjug Chem 25:2101-2104 (2014).

18 Zernia S, Ott F, Bellmann-Sickert K, Frank R, Klenner M, Jahnke HG et al., Peptide-mediated specific immobilization of catalytically active cytochrome P450 BM3 variant. Bioconjug Chem 27:1090-1097 (2016).

19 Tan CY, Hirakawa H, Suzuki R, Haga T and Iwata F, Immobilization of a bacterial cytochrome P450 monooxygenase system on a solid support. Angew Chem Int Ed Engl 55:1-6 (2016). https://doi.org/10 .1002/anie.201608033.

20 Ferrero VEV, Andolfi L, Di Nardo G, Sadeghi SJ, Fantuzzi A, Cannistraro $S$ et al., Protein and electrode engineering for the covalent immobilization of P450 BMP on gold. Anal Chem 80:8438-8446 (2008).

21 Neeli R, Roitel O, Scrutton NS and Munro AW, Switching pyridine nucleotide specificity in P450 BM3: mechanistic analysis of the W1046H and W1046A enzymes. J Biol Chem 280:17634-17644 (2005).

22 Cirino PC and Arnold FH, A self-sufficient peroxide-driven hydroxylation biocatalyst. Angew Chem Int Ed Engl 42:3299-3301 (2003).
23 Vidal-Limón A, Águila S, Ayala M, Batista CV and Vazquez-Duhalt R, Peroxidase activity stabilization of cytochrome P450BM3 by rational analysis of intramolecular electron transfer. J Inorg Biochem 122:18-26 (2013).

24 Sadeghi SJ, Fantuzzi A and Gilardi G, Breakthrough in P450 bioelectrochemistry and future perspectives. Biochim Biophys Acta 1814:237-248 (2011).

25 Holtmann D, Mangold KM and Schrader J, Entrapment of cytochrome P450 BM-3 in polypyrrole for electrochemically- driven biocatalysis. Biotechnol Lett 31:765-770 (2009).

26 Sugihara N, Ogoma Y, Abe K, Kondo Y and Akaike T, Immobilization of cytochrome P-450 and electrochemical control of its activity. Polym Adv Technol 9:307-313 (1998).

27 Munge B, Estavillo C, Schenkman JB and Rusling JF, Optimization of electrochemical and peroxide-driven oxidation of styrene with ultrathin polyion films containing cytochrome P450cam and myoglobin. Chembiochem 6032:82-89 (2003).

28 Chenault HK, Simon ES and Whitesides GM, Cofactor regeneration for enzyme- catalysed synthesis. Biotechnol Genet Eng Rev 6:221-270 (1988).

29 Hollmann F, Hofstetter K and Schmid A, Non-enzymatic regeneration of nicotinamide and flavin cofactors for monooxygenase catalysis. Trends Biotechnol 24:163-171 (2006).

30 Liu W and Wang P, Cofactor regeneration for sustainable enzymatic biosynthesis. Biotechnol Adv 25:369-384 (2007).

31 Lundemo MT and Woodley JM, Guidelines for development and implementation of biocatalytic P450 processes. Appl Microbiol Biotechnol 99:2465-2483 (2015).

32 Schewe $H$, Kaup BA and Schrader J, Improvement of P450BM-3whole-cell biocatalysis by integrating heterologous cofactor regeneration combining glucose facilitator and dehydrogenase in E. Coli. Appl Microbiol Biotechnol 78:55-65 (2008).

33 Beyer N, Kulig JK, Bartsch A, Hayes MA, Janssen DB and Fraaije MW, P450 BM3 fused to phosphite dehydrogenase allows phosphite-driven selective oxidations. Appl Microbiol Biotechnol 101:2319-2331 (2016).

$34 \mathrm{Lu} \mathrm{Y}$ and Mei L, Co-expression of P450 BM3 and glucose dehydrogenase by recombinant Escherichia coli and its application in an NADPH-dependent indigo production system. J Ind Microbiol Biotechnol 34:247-253 (2007).

35 Smith LD, Budgen N, Bungard SJ, Danson MJ and Hough DW, Purification and characterization of glucose dehydrogenase from the thermoacidophilic archaebacterium Thermoplasma acidophilum. Biochem J 261:973-977 (1989).

36 Munishwar, N. G. Methods for Affinity Based Separations of Enzymes and Proteins. Birkhäuser Verlag, Basel-Boston-Berlin, pp 120 (2002).

37 Bradford MM, A rapid and sensitive method for the quantitation of microgram quantities of protein utilizing the principle of protein-dye binding. Anal Biochem 72:248-254 (1976).

38 Laemmli UK, Cleavage of structural proteins during the assembly of the head of bacteriophage T4. Nature 227:680-685 (1970).

39 Omura $T$ and Sato $R$, The carbon monoxide-biding pigment of liver microsomes. J Biol Chem 239:2370-2378 (1964).

40 Guengerich FP, Martin MV, Sohl CD and Cheng Q, Measurement of cytochrome P450 and NADPH - cytochrome P450 reductase. Nat Protoc 4:1245-1252 (2009).

41 Weckbecker A and Hummel W, Glucose dehydrogenase for the regeneration of NADPH and NADH. Microb Enzym Biotransform 17:225-238 (2005).

42 Srivastava PK and Singh S, Immobilization and applications of Glucose-6-phosphate dehydrogenase: a review. Prep Biochem Biotechnol 43:376-384 (2013).

43 Munro AW, Leys DG, KJ ML, Marshall KR, Ost TW, Daff S et al., P450 BM3: the very model of a modern flavocytochrome. Trends Biochem Sci 27:250-257 (2002).

44 Álvaro G, Fernández-Lafuente R, Blanco RM and Guisan JM, Immobilization-stabilization of penicillin $\mathrm{G}$ acylase from Escherichia coli. Appl Biochem Biotechnol 26:181 - 195 (1989).

45 Katchalski-Katzir E and Kraemer DM, Eupergit ${ }^{\circledR}$ C, a carrier for immobilization of enzymes of industrial potential. $J$ Mol Catal B Enzym 10:157-176 (2000).

46 Mateo C, Palomo JM, Fuentes M, Betancor L, Grazu V, López-Gallego F et al., Glyoxyl agarose: a fully inert and hydrophilic support for immobilization and high stabilization of proteins. Enzyme Microb Technol 39:274-280 (2006). 
47 Goheer M a, Gould BJ and Parke DV, Preparation of immobilized baker's-yeast glucose 6-phosphate dehydrogenase attached to modified sepharose and sephadex and a comparison of the properties of these preparations with those of the soluble enzyme. Biochem J 157:289-294 (1976).

48 Persson $M$, Bülow $L$ and Mosbach $K$, Purification and sitespecific immobilization of genetically engineered glucose dehydrogenase on thiopropyl-sepharose. FEBS Lett 270:41-44 (1990).
49 Karuzina II and Archakov Al, The oxidative inactivation of cytochrome P450 in monooxygenase reactions. Free Radic Biol Med 16:73-97 (1994).

50 Petrovičová T, Markošová K, Hegyi Z, Smonou I, Rosenberg M and Rebroš $M$, Co-Immobilization of ketoreductase and glucose dehydrogenase. Catalysts 8:168-176 (2018).

51 Urlacher VB and Girhard M, Cytochrome P450 monooxygenases: perspectives for synthetic application. Trends Biotechnol 24:324-330 (2006). 